\title{
The Role of Philosophy in Twenty-First Century Africa: A Critique of Bodunrin
}

\begin{abstract}
Sunday Olaoluwa Dada*
Department of Philosophy, Ekiti State University, Ado-Ekiti, Ekiti State, Nigeria

Abstract

Philosophy in general and African Philosophy in particular is rocked by the crisis of relevance and is being called upon to justify the huge investment in it by governments. This paper attempts to examine the contributions that philosophy and philosophers can make to the development of African countries. The paper is a counter-discourse to the discourse of scholars like P. O. Bodunrin who thinks that philosophy cannot help in dealing with our present social, moral, religious and economic problems. The paper argues that the professionalization of philosophy which has led to it being treated as a theoretical inquiry does not preclude the capacity of philosophers to reason about the practical problem in the society with a view to providing solutions. It articulates some of the ways by which African philosophers can contribute to social development in Africa such as the development of an ideology, the critique of African values and colonial legacies and the readiness to participate in practical matters so as to translate ideas and theories to social reality. The paper suggests that if philosophers are to be able to be involved in practical matters, there is a need for multi-disciplinary training for them. It concludes by suggesting a philosophy of praxis for Africa.
\end{abstract}

Keyword: Development, Philosophy, Praxis, Professionalization, Relevance

DOI: $10.7176 / \mathrm{DCS} / 9-3-09$

Publication date:March $31^{\text {st }} 2019$

\section{Introduction}

African philosophy as an enterprise has been bedeviled by the crisis of relevance and Africa herself also by the crisis of development. The former can be situated within the purview of professional African philosophers who, in calling for disciplinary purity and in their acceptance of the analytic mode of philosophizing, want philosophy in Africa to remain theoretical. For them, it seems like the criteria for doing African philosophy is being African and philosophical. This is without consideration for the myriads of problems - political instability, debt crisis, corruption, child abuse, brain drain, moral decadence and so on - that rock the boat of African societies today. In this manner, it would be a success on the part of the African philosopher if all he does is to imbibe ideas from, and/or contribute to a philosophical tradition that is not their own. On this view, African philosophy is a theoretical discipline like physics and mathematics and which have specific methods and central problems which constitute its primary preoccupation. On this view also, philosophy in Africa should be related to the core areas of Western philosophy by making contributions to the metaphysics, epistemology, ethics and logic and other areas such as philosophy of language and philosophy of science. It seems as if African philosophy is to be legitimized or delegitimized by Western philosophy. So, if African philosophy is to be properly so-called, it has to be an extension or a copy of Western philosophy both in contents and in method. But philosophy is a cultural activity (Gyekye, 1987: xxxvi). Even what is called Western philosophy is rooted in Western culture. If African philosophers refuse to contextualize their philosophical concerns, they are susceptible to the continuation of the European epistemological ethnocentrism which, for Mudimbe (1988), invented Africa in the first place. Philosophy as a cultural phenomenon implies that African Philosophy has to be grounded in the cultural experience of the African (Gyekye, 1987).

The latter crisis, that is, the crisis of development can be conceptualized as the consequence of, and situated within, the developmental dislocations suffered by Africa as a consequence of colonialism and its subsequent delegitimization of the traditional value system and the rupture of the African economy and politics. There is no doubt that today, even after the exit of colonial governments which gave rise to political independence of African states, Africa still continues to suffer in the hand of the colonialists to the extent that it is almost absurd to speak of the "postcolonial" as if one is to believe that colonial experience has been transcended. In the face of the hegemonic posture of Euro-American politics and economy which dictates the path of development in African states, it only seems reasonable to talk of "neo-colonialism" which is a renewed and disguised colonialism, an attempt to put former colonies under continuous servitude. It should not escape our notice, however, that Africans too share in the blame of the postcolonial woes that betide Africa today. The appropriation of the colonial legacy without due reflection has added to the many problems African states face. This failure can be summed up as the failure of leadership. The leadership of the then newly independent African states felt the exit of the colonialists and the consequent political independence of African state would automatically solve Africa's socio-political and economic maladies. But this was not to be; and today, the leadership of Africa gropes under the problems created by these false expectations. The question to be addressed in this paper is: should African philosophers remain purely theoretical and insensitive in this twenty-first century, making no practical contribution to the rescue of 
Africa from her developmental predicaments, hiding under the cloak of the misrepresentation of philosophy as irrelevant in the day-to-day human affairs?

This paper attempts to examine the contributions that philosophy can make to the development of African countries given the fact that the continent suffers from the problem of development. The paper is a counterdiscourse to that of scholars like Bodunrin who thinks that philosophy cannot help in dealing with our present social, moral, religious and economic problems. The paper argues that the professionalization of philosophy which has led to it being treated as a theoretical inquiry does not preclude the philosophers' capacity to reason about the practical problem in the society with a view to solving them. The paper suggest that if philosophers are to be able to participate actively in practical matters, there is the need for multi-disciplinary training for them. The paper also suggests ways by which African philosophers can contribute to the quest for development in Africa.

\section{Bodunrin on the Role of Philosophy and the Philosopher}

In a paper titled "Philosophy as Pivot in Economic, Social and Political Reorientation", Bodunrin (1990) demonstrates lack of faith in the capability of philosophy and philosophers in dealing with practical matters in the society thereby implying the irrelevance of philosophy in practical matter, which has the further implication that the governments of African states have no justification for any investment in the training of academic philosophers. He contends that:

If it is thought that a philosopher qua philosopher has certain competences which can make him solve our present social, moral, religious and economic problems then I think that would be a mistake (Bodunrin, 1990:11).

He contends further that:

We as philosophers must continue to defend the relevance of philosophy as a theoretical subject and above any claim to practical utility (Bodunrin, 1990:14).

This is akin to the claim of Russell that philosophy is not a discipline that is lacks relevance. The non-relevanceperspective of philosophy only come from those who think from the practical and scientific point of view, that is, those who think that because philosophy does not cater for material needs of man. However, from the perspective of Russell (1974), philosophy is relevant, but only as food for the mind. He writes:

It is exclusively among the goods of the mind that the value of philosophy is to be found; and only those who are not indifferent to these goods can be persuaded that the study of philosophy is not a waste of time (Russell, 1974:89-90).

From this perspective, it seem like philosophy can only thrive as a theoretical and second order discipline and activity. Let us come back to Bodunrin.

One of Bodunrin's convictions for taking this position is that, in contemporary times, philosophizing has become academic and professional to the extent that philosophers are not trained in areas of specializations that could equip them with the competence to meddle in "practical problems". Secondly, he sees the job of the philosophers as merely evaluative of proposed solutions to practical problems. This shows the influence of analytic philosophy on his thought. And thirdly, he believes that social life and experience are pre-reflective, meaning that men do no always act based on philosophical or theoretical reflection and that reflection only comes when we encounter problems. One must be quick to comment on this unacceptable convictions. This will help to point out the inadequacies of Bodunrin's conception of the role of philosophy and philosophers with reference to twentyfirst century Africa.

It is not problematic to agree with Bodunrin that philosophy has been professionalized along with other disciplines such as Economics, Anthropology, Political Science and so on (Bodunrin, 1990). This professionalization truly limits the range of knowledge of professionals in these disciplines. The professionalization of philosophy which has made it more academic in nature has made it more theoretical and distant from daily life (Lachs, 1995). Even though this has the advantage of rigour and deep analysis, it has the problem of philosophers being able to communicated only between themselves without making contributions to the problems and burning issues in the society and by implication making themselves unable to do anything that is concretely useful at all. In Lach's view, for instance:

We live in an age in which philosophy could and should make a difference: the proliferation of divergent commitment and lifestyles, our more ever problematic relation to the environment, our growing complexity and depersonalization of social life and our expanding power to change human nature itself call for better understanding and evaluation (1995:xiii). 
This shows that within the contemporary world, philosophy may lose value if remains theoretical and addresses issues on which knowledge is impossible just for the sake of it. When we look at the problem facing African countries now, it become imperative to q at what philosophy could do to straighten things out. To think as, Bodunrin does, that philosophers cannot make contributions to practical problems, is to have an impoverished and minimalist conception of philosophy and the responsibility of philosophers.

It is pertinent to realize that the professionalization of philosophy should not be a hindrance for the philosopher in dealing with practical issues. This is for the reason that the training of the philosophers which is a training in rationality that sharpens the intellect above the ordinary, equips the philosophers with a considerable amount of special insight into the economic and political problems of the people. This also equips him with the ability to make or offer insightful solutions to some of these problems. It is this insight that qualifies the philosopher to climb down from the philosophical height to delve into practical matters. This does not mean that the philosophers alone can themselves effect the changes required in decadent African societies, however, the knowledge and insight made available can be the basis for revolutionary social and political actions. Apart from this, the professionalization of philosophy does not mean that philosophers in Africa could not train themselves to be multi-disciplinary and so equip themselves with the knowledge required to make contributions to practical problems. This is not a problem since philosophy as a second order discipline engages other discipline especially when it comes to their knowledge claims. African philosophers must not be afraid to contextualize philosophy. This point is made to silence those who may want to argue that multidisciplinary discourse in philosophy is unphilosophical or diversionary. To my mind, the relevance of philosophy lays in it being multidisciplinary and contextual. It is pertinent to suggest therefore that the curriculum of philosophy in African Universities should include courses in politics, Economics, Nation Building and History and International relations. Therefore, rather than lose faith in the philosophers on the ground of professionalization, Bodunrin should have advocated multidisciplinary education for them.

On the formulation of a national ideology, philosophy and economic policies, Bodunrin thinks that the involvement of the philosophers is just that of helping the society to examine itself and to help it to evaluate the merits of alternative proposed solutions (Lachs, 1995). If Bodunrin's position is granted, that is, that philosophers are capable of evaluating the problems generated in the society with an eye for a relevant solution to them, then we must also grant their capacity for a practical direction for the society. My position is that even in the supposedly theoretical exercise of evaluation and clarification of certain societal problems, there is always an implicit prescription of anticipated solution without which the evaluation become a mere exercise in futility.

Bodunrin's observation that actions are pre-reflective seems to relegate philosophical reflections to the background. His observation, to my mind, seems a demonstrated ignorance of the fact that problems and especially social actions, recur in such a way as to validate the fact that history repeats itself constantly. It could be argued that reflection made upon the initial occurrence of such problem in experience could help in dealing with their reoccurrence. Bodunrin also displays an ignorance of this fact.

\section{The Task of the African Philosopher}

What the above analysis demonstrates is that philosophers should not keep quiet when things go wrong in the society. If this elementary point is granted, then to argue as Oguejiofor (2001) does, that the only way philosophy can aid development in the twenty-first Century Africa is through the impartation of the philosophic spirit which allows for the free presentation of one's views and an engagement with the views of others is unacceptable. This attitude, for him, at least relegates dogmatism to the barest minimum in philosophical matters, and makes philosophy true to its nature. One must grant this point, for philosophy in general, even if the issue has nothing to do with Africa's development crisis. Oguejiofor later rightly argues that "philosophers should get more interested in issues that are of burning interest to the society instead of remaining in the ivory towers" (2001:146). One could only interpret this as a recognition of the relevance of the voice of the philosopher in issues of practical importance. To remain at the theoretical level at the expense of a practical involvement betrays a commitment to knowledge merely for its sake; a manifestation of intellectual insensitivity (Oladipo, 2006). The African philosopher should see himself as an intellectual who has a quota to contribute to Africa's search for freedom and development in the postcolonial milieu.

One other African philosopher of the professional school who demonstrates a different attitude to the task and relevance of African philosophy is Kwasi Wiredu. For him, and rightly too, the understanding of the world which philosophers seek is not an end in itself it should be a body of knowledge for the practical good of mankind (Wiredu, 1980:51). If this is correct, then African philosophers need to develop a tradition of philosophizing that employs the tools of philosophy in dealing with some of Africa's perennial problems.

One of Wiredu's recommendations which I find quite agreeable as one of the ways in which African philosophers can contribute to the development of Africa is the need for a critical engagement, reappraisal and reconstruction of Africa's traditional conceptual scheme. This seems to me a plausible suggestion because the appropriation of certain thoughts that developed within a particular cultural context can easily be worked with than 
the domestication of the thoughts that have their origin in other cultures. Such an indigenous appropriation has the added advantage of helping Africa not to lose touch with her own culture even within the necessary demands of cultural dynamism. In this vein, I would want to suggest a point towards the construction of a new metaphysics which can assists in plotting the graph for social harmony and development in Africa. This could be brought about through the reappraisal and reconstruction of the traditional African metaphysics. This is required because at the base of our perception of the world, our social existence, and our religious outlook as Africans is metaphysics. Since, in keeping with the character of philosophy, we cannot expect sameness of reconstruction from philosophers, it is still within the boundary of reason that sameness can be granted if it tends toward the same end. The end serves the purpose of being a guide for social action.

The new metaphysics, for instance, must critically engage the anomalous implications of the over-flogged theory of forces which casts the Africans in an unanalytical frame of mind and presents them as only being capable of a mystical identification with, rather than a conquest of nature. It must also be constructed on the axiom that no culture, no matter, how primitive, can forfeit a critical reflection on its environment and the vicissitudes of its existence. A culture that does not reflect on these, that is, its environment and the vicissitudes of its existence, will cease from being a culture properly so-called.

Also to be engaged in the quest for development are the colonial legacies and edifices upon which African politics and economy are erected. The unreflective appropriation of colonial socio-political and economic structures calls for deconstruction because of the part they played and have continued to play in under-developing Africa. The colonial structures, such as state formation, have continued to promote disunity and ethnic rivalry, weak government and political instability. The required deconstruction cannot be left in the hands of the politicians, economists and scientists alone. In fact they are not competent to deconstruct the new form of colonialism. The reason is that they have become intellectual slaves and prisoners to the West, always joining the bandwagon of ideas developed elsewhere, however irrelevant and pernicious to the African socio-economic and political environment (Oladido, 2006). Philosophers also have an important role to play in this direction, but that role is not to be restricted to the theoretical level. It is then that philosophy can hope to achieve relevance in constructing a new identity for postcolonial Africa.

\section{Conclusion: Philosophy of Praxis}

The crux of this paper is that philosophy matters, not only as food for the mind, or as the development of a critical spirit which allows critical evaluation, but also that philosophy can be married with action that can effect changes in the various aspects of the African societies where there are challenges. This calls for the philosophy of praxis, that is, the need to marry theory and practice in the enterprise called philosophy. At the base of this philosophy is the Marxian expectation that philosophers will not remain at the level of interpretation of reality but should move to the level of transformation. The call for African philosopher to be involved in practical matters is not a call for undue pragmatism or to be involved in pre-reflective action as some policy makers and implementers. The African philosopher is primarily a philosopher. The call for action is to ask him to find a means of translating his philosophical theorization into action. This is germane because most philosophical conferences are not attended by those who can translate philosophical ideas that are produced in the conferences. Okafor laments this when he remarked in one of the conferences held in Nigeria that "our targeted audience, men and women who are in the position to adopt and implement the ideas canvassed by the conference, namely the political class, government bureaucrats, policy makers and administrators... were not only absent but also have deaf ears" (Okafor, 2006:59). Apart from this the products of philosophizing which are published in journals and books are never read by the socalled men of action. Yet until these ideas are translated to social reality, they remain in the realm of mere contemplation. Herein lies the African philosophers' opportunity for positive action. However, in making use of this opportunity, he has to be prepared to participate rather than just be a spectator. The move from contemplation and understanding to action would deal with the marginalization of philosophy in the public sphere and students of philosophy would no longer be afraid of what to do with philosophy.

\section{References}

Bertrand Russell, (1974), The Problem of Philosophy, Oxford: Oxford University Press

Bodunrin, P. O. (1990), "Philosophy as Pivot in Economic, Social and Political Reorientation", Imodoye: $A$ Journal of African Philosophy, Vol. 1, No. 1, 1990, 1-15

Kwame Gyekye, (1987), An Essay on African Philosophical Thought: The Akan Conceptual Scheme. Philadelphia: Temple University Press

Lachs, John, (1995), The Relevance of Philosophy to Life, London: Vanderbilt University

Mudimbe, V. Y. (1988), The Invention of Africa: Gnosis, Philosophy, and the Order of Knowledge, Bloomington: Indiana University Press

Oguejiofor, J. O. (2001), Philosophy and the African Predicament, Ibadan: Hope Publications

Okafor, Fidelis, (2006), "Matching Theory with Praxis to Confront the African Condition", In Martin F. Asiegbu 
and Joseph A. Agbakoba, (Eds.) Philosophy and Praxis in Africa, Ibadan: Hope Publications, 57-67 Oladipo, Olusegun, (2000), The Idea of African Philosophy, Ibadan: Hope Publications

Oladipo, Olusegun, (2006), "Challenges of African Philosophy in the Twenty-first Century", In Olusegun Oladipo (Ed.) Core Issues in African Philosophy. Ibadan: Hope Publications

Wiredu, Kwasi, (1980), Philosophy and an African Culture. Cambridge: Cambridge University Press 